\title{
Evaluation of Low-Stress Herding and Supplement Placement for Managing Cattle Grazing in Riparian and Upland Areas
}

\author{
Derek W. Bailey, ${ }^{1}$ Harv C. VanWagoner, ${ }^{2}$ Robin Weinmeister, ${ }^{3}$ and Delyn Jensen ${ }^{4}$ \\ Authors are ${ }^{1}$ Associate Professor, Department of Animal and Range Sciences, New Mexico State University, Las Cruces, NM 88003, USA; \\ ${ }^{2}$ Former Research Associate, ${ }^{3}$ Former Research Technician, and ${ }^{4}$ Research Technician, Northern Agricultural Research Center, Montana State University, \\ Havre, MT 59501, USA.
}

\begin{abstract}
Management practices are often needed to ensure that riparian areas are not heavily grazed by livestock. A study was conducted in Montana during midsummer to evaluate the efficacy of low-stress herding and supplement placement to manage cattle grazing in riparian areas. Three treatments were evaluated in three pastures over a 3-yr period in a Latin-square design $(n=9)$. Each year, naïve 2-yr-old cows with calves were randomly assigned to the three treatments: 1) free-roaming control, 2) herding from perennial streams to upland target areas, and 3) herding to upland sites with low-moisture block supplements. Stubble heights along the focal stream were higher $(P=0.07)$ in pastures when cattle were herded $(\mathrm{mean} \pm \mathrm{SE}, 23 \pm 2 \mathrm{~cm})$ than in controls $(15 \pm 3 \mathrm{~cm})$. Global positioning system telemetry data showed that herding reduced the time cows spent near $(<100 \mathrm{~m})$ perennial streams $(P=0.01)$ and increased the use of higher elevations $(P=0.07)$ compared with controls. Evening visual observations provided some evidence that free-roaming cows $(44 \% \pm 19 \%)$ were in riparian areas more frequently $(P=0.11)$ than herded cows $(23 \% \pm 6 \%)$. Fecal abundance along the focal stream was less $(P=0.07)$ with herding $\left(61.9 \pm 11.4 \mathrm{~kg} \cdot \mathrm{ha}^{-1}\right)$ than in controls $\left(113.2 \pm 11.4 \mathrm{~kg} \cdot \mathrm{ha}^{-1}\right)$. Forage utilization within $600 \mathrm{~m}$ of supplement sites was greater $(P=0.06)$ when cows were herded to low-moisture blocks $(18 \% \pm 6 \%)$ compared with controls and herding alone $(8 \% \pm 2 \%)$. Moving cattle to uplands at midday using low-stress herding is an effective tool to reduce use of riparian areas. Herding cattle to low-moisture blocks can increase grazing of nearby upland forage but may not provide additional reduction in cattle use of riparian areas compared with herding alone.
\end{abstract}

\section{Resumen}

Las prácticas de manejo a menudo se necesitan para asegurar que las áreas ribereñas no sean fuertemente apacentadas por el ganado. Se condujo un estudio en Montana a mediados del verano para evaluar la eficacia del pastoreo de bajo estrés y la localización del suplemento para manejar el apacentamiento del ganado en las áreas ribereñas. Se evaluaron tres tratamientos en tres potreros durante tres años bajo un diseño de cuadro latino $(n=9)$. Cada año, vacas nativas de dos años con sus becerros fueron asignadas aleatoriamente a los tres tratamientos: 1) movimiento libre, control, 2) pastoreo de corrientes permanentes a áreas específicas en terrenos altos y 3) pastoreo hacia sitios de tierras altas con bloques de suplemento con baja humedad. Las alturas del rastrojo en las corrientes de interés fueron mayores $(P=0.07)$ en los potreros cuando el ganado fue pastoreado (media $\pm \mathrm{EE}$, $23 \pm 2 \mathrm{~cm})$ que en el tratamiento control $(15 \pm 3 \mathrm{~cm})$. Los datos de telemetría del sistema de posicionamiento global mostraron que el pastoreo reduce el tiempo que las vacas pasan cerca $(<100 \mathrm{~m})$ de las corrientes perennes $(P=0.01)$ y aumenta el uso de elevaciones mayores $(P=0.07)$ comparado con el control. Las observaciones visuales nocturnas proveen cierta evidencia de que las vacas con movimiento libre $(44 \% \pm 19 \%)$ estuvieron más frecuentemente en las áreas ribereñas $(P=0.11)$ que las vacas pastoreadas $(23 \% \pm 6 \%)$. La abundancia fecal a lo largo de las corrientes estudiadas fue menor $(P=0.07)$ con pastoreo $\left(61.9 \pm 11.4 \mathrm{~kg} \cdot \mathrm{ha}^{-1}\right)$ que en el control $\left(113.2 \pm 11.4 \mathrm{~kg} \cdot \mathrm{ha}^{-1}\right)$. La utilización del forraje dentro de un radio de $600 \mathrm{~m}$ del suplemento fue mayor $(P=0.06)$ cuando las vacas fueron pastoreadas a los bloques de suplemento $(18 \% \pm 6 \%)$ en comparación con el control y el pastoreo solo $(8 \% \pm 2 \%)$. Mover el ganado hacia los terrenos altos al mediodía, usando técnicas de bajo estrés, es una herramienta efectiva para reducir el uso de las áreas ribereñas. Pastorear el ganado hacia las áreas con bloques de suplemento bajos en humedad puede incrementar el apacentamiento del forraje cercano a los sitios de terrenos altos, pero puede no proveer una reducción adicional del uso de las áreas ribereñas por el ganado, en comparación con el pastoreo solo.

Key Words: distribution, grazing behavior, herding, riparian areas, supplement blocks

\section{INTRODUCTION}

Research was funded by the USDA Initiative for Future Agricultural and Foods Systems program.

Correspondence: Derek W. Bailey, Dept of Animal and Range Sciences, New Mexico State University, PO Box 30003, MSC 3-I, Las Cruces, NM 88003, USA. Email: dwbailey@nmsu.edu

Manuscript received 7 October 2006; manuscript accepted 23 October 2007.
Livestock grazing in riparian areas continues to be a critical issue on private and public rangelands in the western United States (Del Curto et al. 2005). Cattle spend a disproportionate amount of time in riparian areas (Roath and Kruegar 1982; Smith et al 1992). Cattle use near streams usually increases and 
becomes a greater concern during mid to late summer when temperatures rise and upland forage quality begins to decline (Parsons et al. 2003).

Herding has been suggested as a tool for modifying cattle grazing for years (e.g., Skovlin 1957; Bailey 2004; DelCurto et al. 2005). Despite numerous recommendations, we are not aware of any replicated studies that have evaluated the effectiveness of herding to reduce cattle use of riparian areas. Butler (2000) reported that intensive herding successfully reduced cattle use of riparian areas in an anecdotal study in Idaho. Smith (1998) suggested that the low-stress livestock handling techniques developed by Bud Williams might increase the effectiveness of herding over conventional handling techniques and potentially make it a more powerful management tool.

During mid to late summer, when cattle preference for riparian areas is at its highest level, several practices may be required to modify grazing patterns (Parsons et al 2003; DelCurto et al. 2005). Strategic supplement placement has been an effective tool for modifying cattle grazing patterns in foothill rangeland during the fall and winter (Bailey and Welling 1999). Cattle use of underused rangeland can be increased in areas up to $600 \mathrm{~m}$ from where low-moisture blocks (LMB) are placed (Bailey et al. 2001).

The objective of this study was to evaluate the efficacy of low-stress herding and strategic supplement placement to reduce cattle grazing near streams and to correspondingly increase grazing on uplands. We hypothesized that low-stress herding would reduce cattle grazing near key streams and that placement of supplement in uplands would complement herding and further decrease cattle use of riparian areas and increase upland grazing near supplement sites.

\section{METHODS}

The experimental procedures used in this study were reviewed and approved by the Montana State University Agricultural Animal Care and Use Committee (Protocol AA-015).

\section{Study Site}

The study was conducted in the Lake Pasture (1679 ha) of the Bair Ranch, located $24 \mathrm{~km}$ east of White Sulphur Springs, Montana (lat $46^{\circ} 37^{\prime} \mathrm{N}$, long $110^{\circ} 36^{\prime} \mathrm{W}$ ). The pasture was bisected by the North Fork of the Musselshell River, and Bair Reservoir formed part of the southeast pasture boundary. Soils were primarily loams or clay loams. Upland vegetation was dominated by big sagebrush (Artemisia tridentata Nutt.) and Idaho fescue (Festuca idahoensis Elmer). Riparian areas were dominated by willows (Salix spp), Kentucky bluegrass (Poa pratensis L.), and beaksedge (Carex rostrata Stokes). Average annual precipitation in nearby White Sulphur Springs, Montana, is $340 \mathrm{~mm}$. Average daily temperatures vary from $-6^{\circ} \mathrm{C}$ in January to $18^{\circ} \mathrm{C}$ in July, with daily maximum temperatures sometimes exceeding $35^{\circ} \mathrm{C}$ in the summer, and minimum temperatures in the winter occasionally dropping below $-38^{\circ} \mathrm{C}$.

The Lake Pasture was divided into three paddocks using electric fences. The goal of the fencing was to provide similarsized paddocks with equivalent segments (approximately $600 \mathrm{~m}$ ) of the North Fork of the Musselshell River and areas
Table 1. Area, topographic relief, and relative water locations for the three paddocks used in the study. ${ }^{1}$

\begin{tabular}{lccc}
\hline & \multicolumn{3}{c}{ Paddock } \\
\cline { 2 - 4 } Attribute & North & Middle & South \\
\hline Size, ha & 541 & 591 & 556 \\
Slope, ${ }^{\circ}$ & & & \\
Mean & 3.1 & 5.8 & 6.9 \\
Minimum & 0 & 0 & 0 \\
Maximum & 13.7 & 25.1 & 47.2 \\
SD & 2.3 & 3.9 & 4.8 \\
Elevation, m & & & \\
Mean & 1691 & 1677 & 1684 \\
Minimum & 1653 & 1619 & 1622 \\
Maximum & 1736 & 1793 & 1797 \\
SD & 12.8 & 28.9 & 40.4 \\
Distance to water, $m$ & & & \\
Mean & 389 & 481 & 510 \\
Minimum & 0 & 0 & 0 \\
Maximum & 1184 & 1286 & 1839 \\
SD & 279 & 327 & 418 \\
\hline
\end{tabular}

${ }^{1}$ Values are calculated from $9 \times 9 \mathrm{~m}$ grid cells derived from a digital elevation model (US Geologic Survey) using ArcView geographic software (ESRI, Redlands, CA).

of rugged topography (Table 1 ). Despite these efforts, the paddocks differed in many respects, including the inclusion of an irrigation canal in the North paddock and Bair Reservoir in the Middle and South paddocks. All paddocks had multiple sources of water, but the irrigation canal provided a water source in the North paddock that was not associated with a stream (Fig. 1). The water level in Bair Reservoir changed rapidly during all $3 \mathrm{yr}$ of the study (2002-2004). As water levels in Bair Reservoir dropped, foxtail barley (Hordeum jubatum L.) quickly established in many parts of the exposed lake bottom. If vegetation became established, the areas were considered as riparian zones. Cattle readily used portions of the lake bottom where foxtail barley grew but generally avoided areas with bare ground.

The North Fork of the Musselshell River was a logical focal point for riparian area management because it contained an active fishery of brook trout (Salvelinus fontinalis) and previous grazing levels in the associated riparian areas had sometimes been heavy (J. Murphy, personal communication, May 2002). It was by far the largest stream in the Lake Pasture with the channel exceeding $2 \mathrm{~m}$ in width in most areas. The Musselshell was also in an ideal location for a grazing distribution study because it flowed roughly through the middle of the paddocks (Fig. 1).

In addition to the North Fork of the Musselshell River, each paddock also contained a single smaller, perennial stream that was a tributary to the Musselshell River. These tributary streams were distinguished from water sources and riparian areas because they were perennial, at least $1 \mathrm{~m}$ wide and $8 \mathrm{~cm}$ deep in most areas, and flowed throughout their reach in the paddock. Other streams within the paddock were ephemeral and dry during at least part of the study.

Fence boundaries and the extent of available water in Bair Reservoir, irrigation canals, springs, and perennial and ephemeral streams were recorded using a global positioning 


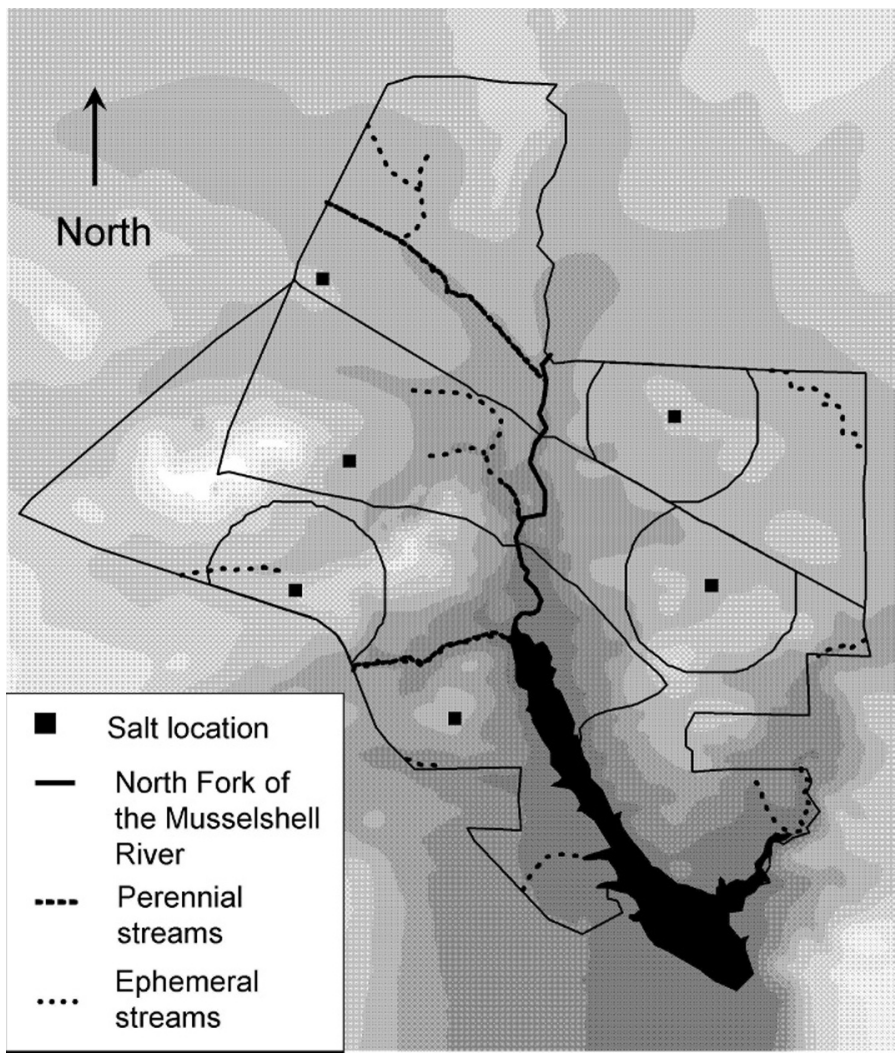

Figure 1. Map of the Lake Pasture study area. The pasture was divided into three paddocks (North, Middle, and South). The North Fork of the Musselshell River flowed through the middle of the paddocks. Paddock shape was designed so that each paddock included roughly $600 \mathrm{~m}$ of the Musselshell River. Paddocks also included at least one other perennial stream and ephemeral streams. An irrigation ditch was located on the northwest corner of the North Paddock. Each paddock contained two sites where salt was placed during each year of the study. One of the two sites was randomly selected as a target for herding. The area within $600 \mathrm{~m}$ of the selected salt site was considered as a target area and is shown as a circle around a salt site. Higher elevations are indicated by lighter background colors.

system receiver with an accuracy within $3 \mathrm{~m}$. A 1:24 000-scale digital elevation model (US Geological Survey [USGS]) was used to determine slopes and elevations within the paddocks using ArcView Version 3.3 (2002) geographic software (ESRI, Redlands, California).

\section{Treatments}

The study consisted of three treatments: herding (HERD), herding with strategic supplementation (HERD-SUPP), and control. In the herding treatment, cattle observed within $200 \mathrm{~m}$ of the Musselshell River or a perennial tributary stream at midday (1100-1230) were herded to the placement site containing a salt block $(99 \% \mathrm{NaCl}, 22.7 \mathrm{~kg})$ located 1.0 $2.0 \mathrm{~km}$ away. Cattle that were farther than $200 \mathrm{~m}$ from the Musselshell and perennial tributaries were not herded. The HERD-SUPP treatment was identical to HERD treatment except that cattle were herded to the placement site that contained both a salt block and 4 LMB $(113.4 \mathrm{~kg})$. LMB used in this study were similar to that used in other studies (Bailey and Welling 1999, Bailey et al. 2001) evaluating the efficacy of strategic supplement placement to modify cattle distribution, except that these LMB contained $20 \%$ crude protein $(\mathrm{CP})$ rather than the $30 \% \mathrm{CP}$ used in previous studies. The LMB were placed between 40 and $80 \mathrm{~m}$ apart and between 40 and $80 \mathrm{~m}$ from salt. In the control treatment, cow-calf pairs were allowed to roam freely within a paddock. Salt blocks were also available in the control treatment and were placed in the same locations as the HERD and HERD-SUPP treatments.

The goal of the HERD and HERD-SUPP treatments was to allow cattle to drink, but not remain near the perennial streams. Typically, cattle move to streams and other water locations in midmorning and remain there until evening (Porath et al. 2002; Parsons et al. 2003; Bailey et al. 2004). Herding cattle away from streams at midday after they drink can potentially reduce the time spent in riparian areas and reduce animal impacts on stream banks and associated vegetation. Butler (2000) reported anecdotal observations where a similar approach of herding at midday was successful in protecting riparian areas in southern Idaho.

Cattle were herded using low-stress techniques developed by Bud Williams and described in Smith (1998). One or two riders on horseback herded the cattle. On most days, the herding required 1-2 h to move the cattle from the streams to the target area.

\section{Experimental Design}

The study was designed as a Latin-square. The three treatments (Control, HERD and HERD-SUPP) were randomly assigned so that each treatment was evaluated in each of the three paddocks (North, Middle and South), and all three treatments were evaluated during each year $(2002,2003$, and 2004) of the 3 -yr study. We attempted to implement the treatments similarly each year. Cattle remained in the study paddocks from midJuly to mid-August for 27-29 d. Cattle were herded to the same location in each paddock when first released-the permanent water closest to the livestock-handling facilities located on the west end of the paddocks.

Supplement sites did not change during the study. Salt was always available in the same locations (two locations per paddock, each located $1-2 \mathrm{~km}$ from perennial streams) throughout the study (Fig. 1). One of the two salting sites in each paddock was randomly selected as the target. Cattle were herded to the same target area in each paddock during the study. For the HERD-SUPP treatment, this site contained both salt and LMB. The area within $600 \mathrm{~m}$ of this salt placement was considered the target area. Bailey et al. (2001) reported that the impact of $\mathrm{LMB}$ on cattle grazing distribution declined rapidly at distances greater than $600 \mathrm{~m}$ from placement sites.

\section{Cattle}

Naïve 2-yr-old, first-calf, Angus or Angus-Hereford-cross cows with calves were used during each year of the study. Cows were raised at the Bair Ranch and had grazed in pastures near the Lake Pasture as calves and yearlings. Cow-calf pairs were randomly assigned to treatment groups. Each treatment group contained 52, 59, and 42 cow-calf pairs during 2002, 2003, and 2004, respectively. Each group of cow-calf pairs also included two Angus bulls. Cattle numbers varied annually 
because of availability. All 2-yr-old cows at the Bair Ranch were used in the study.

\section{Cattle Tracking}

Lotek global positioning system (GPS) 2200 collars (Lotek Wireless, Newmarket, Canada) were placed on four or five randomly selected cows in each treatment group. Collars remained on the same cows while in the study paddocks (27$29 \mathrm{~d}$ ). Positions were recorded every $15 \mathrm{~min}$. Positions were differentially corrected using GPS base-station data from Helena, Montana, located $110 \mathrm{~km}$ from the study site. Accuracy of differentially corrected positions from these collars is within $7 \mathrm{~m}$ (Moen et al. 1997).

The slope, elevation, distance from the North Fork of the Mussellshell River, distance from a perennial stream and distance from available water (includes irrigation ditch and Bair Reservoir) were determined from each position obtained from collared cows. In addition, the time spent within $100 \mathrm{~m}$ of the Musselshell River and other perennial streams and ephemeral streams was calculated. The time spent within $100 \mathrm{~m}$ of streams was used as an indicator of the time spent by cattle in riparian areas and other nearby areas that could be impacted by grazing because the actual locations of riparian areas in the Lake pasture had not been mapped precisely enough to distinguish if GPS collared cows positions were in or out of riparian areas. Riparian areas in the Lake pasture did not extend further than $100 \mathrm{~m}$ from streams.

Telemetry data from each collared cow were averaged together, and the means from collared cows in a paddock in a given year were then averaged to give one value from each paddock each year $(n=9)$.

\section{Cattle Observations}

Observers recorded locations of cattle during mornings (0630-0800 hours) and evenings (1900-2030 hours) during the study. During 2002, locations were recorded on $12 \mathrm{~d}$. The number of observations was increased during 2003 and 2004 to improve precision ( $24 \mathrm{~d}$ in 2003 and $26 \mathrm{~d}$ in 2004). Observers recorded the number of cattle observed while driving established routes through the paddocks and stopping at strategic observations points. Paddocks were divided into $200 \times 200 \mathrm{~m}$ grid cells. Observers recorded the number of cows located in each grid cell. Although it took $1-1.5 \mathrm{~h}$ to drive the established routes and observe cattle locations, our goal was to obtain a single-scan sample of cattle locations in the three paddocks. The order in which routes were driven was randomized to minimize bias.

The average elevation, slope, distance from water, and distance from the Musselshell River were calculated for each grid cell using the USGS digital elevation model and ArcView geographic information system software. The average observed slope use, elevation, distance from water, and distance from the Musselshell River were calculated from each 1.5-h observation period using a weighted average from the proportion of observed cows in a grid cell and the associated slopes, elevation, and distances values for the cell. These values were then averaged for each year of the study for a total of nine values from the morning observations and nine values from the evening observations (three paddocks for $3 \mathrm{yr}$ ).
Grid cells that included a perennial stream or grid cells that contained over $25 \%$ riparian vegetation based on ocular reconnaissance were classified as riparian. The area exposed when Bair Reservoir water levels dropped and vegetation became established was also considered as riparian. The remaining cells were classified as upland. Each year, the mean proportion of the cows within a paddock observed in grid cells classified as riparian were determined for the morning and evening observation periods.

\section{Standing Crop and Forage Quality}

Each year, standing crop was estimated in riparian areas and on uplands before and after grazing to get a rough estimate of forage availability. Forage was clipped in $0.1-\mathrm{m}^{2}$ frames and separated into forbs and grasses (including sedges). Samples were dried for $48 \mathrm{~h}$ at $50^{\circ} \mathrm{C}$ and weighed. On upland areas, 10 randomly selected grid cells were selected in each paddock at the beginning of the study. Each year, frames were placed randomly within these grid cells and clipped. However, some standing crop data were lost, and a few additional randomly selected locations were sampled. The number of frames clipped within a paddock varied from 9 to 13 during each measurement. Standing crop estimates in riparian areas were determined similarly with four to six frames measured in each paddock. Standard errors for standing-crop estimates are based on the number of clipped frames.

Clipped samples within a paddock were pooled and analyzed for $\mathrm{CP}$ and acid detergent fiber (ADF), which gave annual estimates of quality from riparian and upland grasses in each paddock before and after grazing.

\section{Fecal Abundance}

Four $2 \times 40 \mathrm{~m}$ permanent transects were established in each paddock on randomly selected locations in the riparian areas associated with North Fork of the Musselshell River. Two additional transects within each paddock were established in random locations within other riparian areas. Ten $2 \times 40 \mathrm{~m}$ permanent transects were established in each paddock at randomly selected upland sites. In early July, before the cattle were released into paddocks, all cattle fecal pats were removed from the permanent transects. In late August, after cattle were removed from the paddocks, fecal pat abundance was estimated from all transects using the methodology described by Tate et al. (2000), where fecal pats are classified by size and counted to estimate the dry weight of feces per unit area. Each year, values from a site category (Musselshell, other riparian, and upland) within a paddock were averaged together and used in the analyses.

\section{Stubble Height}

After grazing ended in late August, stubble heights in riparian areas were measured along 40-m transects. Stubble height was measured every $2 \mathrm{~m}$ for a total of 20 measurements transect $^{-1}$. Along the North Fork of the Musselshell River, stubble heights were observed at the four fecal-abundance transects and at an additional six randomly selected transects for a total of 10 locations in each paddock. At other riparian areas, stubble height was measured at the other two fecal-abundance plots and at four additional randomly selected locations. The 
additional transects were not permanently marked and were placed at different locations each year. Stubble heights along the Musselshell River $(n=9)$ and the other riparian areas $(n=9)$ were averaged together for one value for a paddock each year.

\section{Forage Utilization}

Forage utilization was measured on uplands after grazing ended in mid August along 40-m transects using the height-weight procedure described by Cook and Stubbendieck (1986). Published height-weight relationships (US Forest Service 1980) were used for most grasses and height-weight curves were developed for Kentucky bluegrass (Poa pratensis L.), rough fescue (Festuca scabrella Torr.), and smooth brome (Bromus inermis Leyss.), which are not included in the published information. Forage utilization was calculated from stubble heights using these height-weight curves.

Forage utilization was estimated at the 10 upland fecalabundance transects and at an additional 10 randomly selected $200 \times 200 \mathrm{~m}$ grid cells for a total of 20 locations within each paddock. For the additional locations, measurements were collected in the same grid cell during the study, but the location within a grid cell was randomly selected each year.

\section{Statistical Analyses}

Analyses of telemetry data, morning and evening cow observations, stubble heights, and fecal abundance were analyzed as a Latin square $(n=9)$. Year $(2002,2003$, and 2004) and paddock (North, Middle, and South) were used as blocking factors. Latin-square designs assume that there are no block-bytreatment interactions and are not typically used in range studies because of the possibility of such interactions (Krysl et al. 1989). In addition, Lucas (1957) expressed concerns with Latin-square designs because of the potential for residual effects of the treatments on blocking factors. In this study, the pasture had historically been grazed with sheep and cattle at much higher levels of stocking than the light levels used in this study (9-14 ha per animal unit month), so it is unlikely that treatments would have residual effects on subsequent grazing patterns. The use of naïve cattle each year also reduced the possibility of residual treatment effects. Even if there are treatment-by-period interactions, treatment comparisons are still valid (Krysl et al. 1989). The presence of block (row or column)-by-treatment interactions in Latin-square designs leads to an overestimation of the error term (Wilk and Kempthorne 1957) and makes treatment comparisons conservative in nature.

The statistical model included year (2002, 2003, and 2004), paddock (North, Middle, and South), and treatment (Control, HERD, and HERD-SUPP). One-degree-of-freedom, orthogonal contrasts were used to evaluate the planned comparisons of herded (HERD and HERD-SUPP) vs. free-roaming (Control) and HERD vs. HERD-SUPP treatments.

Percentage data, such as time spent near streams, riparian areas, and target areas, were also analyzed after a square root transformation (Steel and Torrie 1980). Results from transformed data were very similar to that of untransformed data. Analyses using untransformed data are presented for ease of interpretation. Most of the percentage data (time spent in an area) were converted to hours per day $\left(h \cdot d^{-1}\right)$ after analyses to help the reader better identify differences in values.

Forage-utilization transects that were within a target area (within $600 \mathrm{~m}$ of salt and the endpoint of herding) were averaged together $(n=9)$. These data and forage quality estimates before and after grazing were then analyzed as a Latin square with a model containing year, paddock, and treatment. As in the other analyses, one-degree-of-freedom, orthogonal contrasts were used to evaluate the planned comparison of herded (HERD and HERD-SUPP) vs. freeroaming (Control) cattle. In addition, we also used an orthogonal contrast to compare forage utilization when supplement (HERD-SUPP) was available vs. when no supplement was available (Control and HERD). Previous research (Bailey and Welling 1999) showed that upland forage utilization increased when LMB and salt were placed on uplands compared with when only salt was available. Paired comparisons of the HERD-SUPP treatment with the control and HERD treatments were also evaluated using a Student's $t$ test (SAS 1999).

In evaluations of treatment effects from the Latin-square analyses $(n=9)$, we describe means as different when $P$ values were $\leq 0.10$. If treatment rankings were consistent across the three paddocks, we discuss treatment means and standard errors even though the corresponding $P$ values varied from 0.11 to 0.17 . Johnson (1999) argues that $P$ values are arbitrary and that consistent results observed across valid replications is the key to interpretation of experimental results. Our rationale for the discussion is to allow the reader to examine differences in treatments across all responses even though evidence provided by any one response is limited. With large-scale studies, it is usually impractical to obtain large sample sizes, and the corresponding experimental error and uncertainty of results can be greater than in smaller-scale studies where more replications can be completed. Descriptions of means as different or similar are included only to make the discussion more concise. Readers are cautioned to make their own interpretation of statistical and, more important, biological significance.

Upland forage utilization measurements were analyzed using analysis of covariance (Littell et al. 1996) to determine whether uniformity of grazing differed between treatments. The statistical model included year and paddock as fixed effects to adjust forage utilization values collected annually in each paddock to a common value. Treatment was included as a fixed effect to determine whether there were differences in the linear relationships (regression coefficients) between forage use and terrain attributes (elevation, slope, and horizontal distance to water). Continuous effects in the model included terrain attributes and interaction between treatment and terrain attributes. Important interactions between treatment and the continuous variables (terrain attributes) would suggest that the relationship between forage use and terrain (e.g., slope) varied between treatments.

\section{RESULTS}

\section{Forage Quantity and Quality}

Forage quantity and quality were generally similar during the $3 \mathrm{yr}$ of the study (Table 2). Standing crop of grasses in riparian 
Table 2. Mean standing crop ( $\pm \mathrm{SE}$ ) and forage quality of grasses in upland and riparian areas before and after grazing during the $3 \mathrm{yr}$ of the study.

\begin{tabular}{|c|c|c|c|c|c|}
\hline \multirow[b]{2}{*}{ Attribute } & \multirow[b]{2}{*}{ Timing } & \multicolumn{3}{|c|}{ Year } & \\
\hline & & 2002 & 2003 & 2004 & \\
\hline \multicolumn{6}{|c|}{ Standing crop, $\mathrm{kg} \cdot \mathrm{ha}^{-1}$} \\
\hline \multirow[t]{2}{*}{ Upland grass } & Before & $640 \pm 70$ & $610 \pm 80$ & $560 \pm 90$ & \\
\hline & After & $500 \pm 110$ & $740 \pm 110$ & $470 \pm 120$ & \\
\hline \multirow[t]{2}{*}{ Riparian grass } & Before & $1400 \pm 170$ & $1460 \pm 190$ & $1360 \pm 180$ & \\
\hline & After & $900 \pm 190$ & $1160 \pm 190$ & $1460 \pm 190$ & \\
\hline \multirow[t]{2}{*}{ Upland forbs } & Before & $270 \pm 30$ & $230 \pm 30$ & $240 \pm 30$ & \\
\hline & After & $180 \pm 50$ & $380 \pm 50$ & $220 \pm 50$ & \\
\hline \multirow[t]{2}{*}{ Riparian forbs } & Before & $360 \pm 100$ & $510 \pm 110$ & $380 \pm 110$ & \\
\hline & After & $270 \pm 50$ & $420 \pm 50$ & $170 \pm 50$ & \\
\hline Grass quality & & & & & Pooled SE \\
\hline \multicolumn{6}{|l|}{ Crude protein, $\%$} \\
\hline \multirow[t]{2}{*}{ Upland } & Before & 8.12 & 7.42 & 8.61 & 0.17 \\
\hline & After & 7.51 & 6.76 & 6.17 & 0.48 \\
\hline \multirow[t]{2}{*}{ Riparian } & Before & 9.87 & 7.94 & 9.75 & 0.54 \\
\hline & After & 7.74 & 7.59 & 7.77 & 0.68 \\
\hline \multicolumn{6}{|c|}{ Acid detergent fiber, \% } \\
\hline \multirow[t]{2}{*}{ Upland } & Before & 40.9 & 40.0 & 36.7 & 1.1 \\
\hline & After & 39.6 & 40.9 & 37.9 & 1.7 \\
\hline \multirow[t]{2}{*}{ Riparian } & Before & 38.9 & 36.2 & 32.6 & 1.3 \\
\hline & After & 37.0 & 38.6 & 36.8 & 1.9 \\
\hline
\end{tabular}

areas was roughly 2 times higher than in uplands before grazing. Differences between riparian areas and uplands were not as apparent after grazing. CP concentration after grazing and ADF both before and after grazing did not vary among paddocks or treatments $(P>0.20)$. CP in upland grasses before grazing differed among years $(P=0.08)$, but CP of upland grasses after grazing and $\mathrm{CP}$ of riparian grasses did not differ among years $(P>0.20)$. ADF did not differ among years for upland or riparian grasses $(P>0.15)$.

\section{Frequency of Herding}

Cow-calf pairs in the HERD treatment were herded away from the Mussellshell River or the other perennial streams to the upland target areas on $57.2 \pm 18.7 \%$ of the study days, whereas cattle in the HERD-SUPP treatment were herded on $63.0 \pm 16.9 \%$ of study days. On days that cattle were observed in riparian areas of perennial streams at midday, $83.3 \pm 12.4 \%$ of the cows from the HERD treatment and $68.6 \pm 4.9 \%$ of the cows from the HERD-SUPP were present and moved to the upland target areas.

\section{Terrain Use of GPS-Collared Cows}

Cows that were herded (HERD and HERD-SUPP pooled) used $19 \pm 5 \mathrm{~m}$ higher $(P=0.07)$ elevations than free-roaming control cows based on telemetry data (Table 3). The HERD and HERD-SUPP treatments did not differ $(P=0.78)$ in their use of higher and lower elevations. Cows from all treatments used similar slopes $(P=0.61)$.

Telemetry data provided some evidence that herding increased the distance cows were from perennial and ephemeral streams $(305 \pm 147 \mathrm{~m})$ compared with controls $(P=0.17)$. The presence or absence of supplement did not affect $(P>0.20)$ the distance herded cows were from water or from streams (Table 3). In a subsequent analysis, the North Fork of the

Table 3. Terrain use by global positioning system-collared cows that were herded to salt (HERD), herded to salt and low-moisture block supplements (HERD-SUPP), and allowed to roam freely (control). Orthogonal contrasts were used to compare cows that were herded (HERD and HERD-SUPP pooled) with controls and to compare the HERD and HERD-SUPP treatments.

\begin{tabular}{|c|c|c|c|c|c|c|}
\hline \multirow[b]{2}{*}{ Attribute } & \multicolumn{4}{|c|}{ Treatment means } & \multicolumn{2}{|c|}{ Orthogonal contrasts ${ }^{1}$} \\
\hline & Control & HERD & HERD-SUPP & SE & $\begin{array}{l}\text { Herded vs. } \\
\text { control }\end{array}$ & $\begin{array}{l}\text { HERD vs. } \\
\text { HERD-SUPP }\end{array}$ \\
\hline Slope, ${ }^{\circ}$ & 4.3 & 4.3 & 4.0 & 0.2 & 0.64 & 0.42 \\
\hline Elevation, m & 1658 & 1678 & 1676 & 4 & 0.07 & 0.78 \\
\hline Distance to water, m & 143 & 264 & 247 & 41 & 0.15 & 0.80 \\
\hline Distance from ephemeral and perennial streams, $\mathrm{m}$ & 302 & 544 & 669 & 120 & 0.17 & 0.53 \\
\hline Distance from the Musselshell River, $\mathrm{m}$ & 1119 & 1373 & 1289 & 206 & 0.48 & 0.80 \\
\hline Distance traveled, $\mathrm{km} \cdot \mathrm{d}^{-1}$ & 4.40 & 5.67 & 5.70 & 0.24 & 0.05 & 0.94 \\
\hline
\end{tabular}

${ }^{1} P$ values from the orthogonal contrasts are presented. 
Table 4. Time spent within $100 \mathrm{~m}$ of streams and water $\left(\mathrm{h} \cdot \mathrm{d}^{-1}\right)$ by global positioning system-collared cows that were herded to salt (HERD), herded to salt and low-moisture block supplements (HERD-SUPP), and allowed to roam freely (control). Orthogonal contrasts were used to compare cows that were herded (HERD and HERD-SUPP pooled) with controls and to compare the HERD and HERD-SUPP treatments.

\begin{tabular}{lcccccc}
\hline & \multicolumn{3}{c}{ Treatment means } & \multicolumn{2}{c}{ Orthogonal contrasts $^{1}$} \\
\cline { 2 - 5 } Time $\left(\mathrm{h} \mathrm{d}^{-1}\right)$ spent within $100 \mathrm{~m}$ of & Control & HERD & HERD-SUPP & SE & Herded vs. control & HERD vs. HERD-SUPP \\
\hline Musselshell River & 4.1 & 2.4 & 2.6 & 0.7 & 0.20 \\
Perennial streams & 7.8 & 4.8 & 5.7 & 0.4 & 0.04 & 0.87 \\
Perennial and ephemeral streams & 12.4 & 8.0 & 7.5 & 1.0 & 0.07 & 0.27 \\
All water & 14.4 & 10.7 & 10.4 & 1.3 & 0.13 & 0.78 \\
\hline
\end{tabular}

${ }^{1} P$ values from the orthogonal contrasts are presented.

Musselshell River was distinguished from other perennial streams. There were no differences $(P=0.72)$ among treatments in the mean distance from Musselshell River.

Cows that were herded traveled $1.3 \pm 0.3 \mathrm{~km}$ farther each day $(P=0.05)$ than free-roaming cows (Table 3$)$. Distance traveled by the HERD-SUPP treatment was similar to the HERD treatment $(P=0.94)$.

\section{Time Spent Near Streams by GPS-Collared Cows}

Herded cows spent $2.6 \pm 0.5 \mathrm{~h} \cdot \mathrm{d}^{-1}$ less time within $100 \mathrm{~m}$ of perennial streams $(P=0.04)$ and $4.6 \pm 1.2 \mathrm{~h} \cdot \mathrm{d}^{-1}$ less time within $100 \mathrm{~m}$ of all streams (perennial and ephemeral combined, $P=0.07$ ) than free-roaming control cows (Table 4). Analyses of time spent within $100 \mathrm{~m}$ of all water sources provided some evidence $(P=0.13)$ that free-roaming cows spent more time near water $\left(3.9 \pm 1.6 . \mathrm{h} \cdot \mathrm{d}^{-1}\right)$ than herded cows. However, herded cows did not spend less time $(P=0.20)$ within $100 \mathrm{~m}$ of the Musselshell than control cows (Table 4). The HERD and HERD-SUPP treatments were within $100 \mathrm{~m}$ of streams and water for approximately the same amount of time $(P>0.20)$.

The area within $100 \mathrm{~m}$ of perennial streams made up $9 \%$ of the study area. Free-roaming control cows spent $33 \pm 2 \%$ of their time within $100 \mathrm{~m}$ of perennial streams, whereas herded cows spent $22 \pm 2 \%$ of their time in that area. The area within $100 \mathrm{~m}$ of perennial and ephemeral streams made up $15 \%$ of the study area. Control cows spent $52 \pm 4 \%$ of their time in those areas, whereas herded cows spent $32 \pm 4 \%$.

\section{Supplement Intake}

During 2002, 2003, and 2004, cattle consumed 159, 426, and $410 \mathrm{~g} \cdot \mathrm{d}^{-1}$ of LMB in the South, Middle, and North paddocks, respectively. Salt intake did not vary among treatments $(P=0.88)$ and averaged $18 \pm 4 \mathrm{~g} \cdot \mathrm{d}^{-1}$ during the study.

\section{Time Spent Near the Upland Target by GPS-Collared Cows}

Cows that were herded to the upland target areas spent more time $(P \leq 0.10)$ within $100,200,400$, and $600 \mathrm{~m}$ of the target than free-roaming control cows (Table 5). Cows that were herded spent $3.9 \pm 0.3 \mathrm{~h} \cdot \mathrm{d}^{-1}$ more time within $600 \mathrm{~m}$ of the target than controls. Cows in the HERD-SUPP treatment did not spend any more time within 100, 200, 400, and $600 \mathrm{~m}$ of the target than the HERD treatment $(P \geq 0.19)$.

\section{Observations of the Cow Herd}

In the morning, there were no differences $(P>0.20)$ among treatments for utilization of slopes, distance from water, and time spent in areas with riparian zones (Table 6). In the evening, cows that were herded were $152 \pm 48 \mathrm{~m}$ farther $(P=0.09)$ from all water sources than controls. There is also limited evidence from evening observations that cows that were herded used $24 \pm 11 \mathrm{~m}$ higher elevations $(P=0.17)$ and were $370 \pm 154 \mathrm{~m}$ farther $(P=0.13)$ from the Musselshell River than free-roaming controls. Observations of the HERD and HERD-SUPP treatments were similar during the morning and evening observation periods $(P>0.20)$.

\section{Fecal Abundance}

In riparian areas associated with the North Fork of the Musselshell River, fecal abundance was $51.3 \pm 14.0 \mathrm{~kg} \cdot \mathrm{ha}^{-1}$ less $(P=0.07)$ if cattle were herded than if allowed to roam freely (control). In other riparian areas and in uplands there were no differences $(P>0.20)$ in fecal abundance between treatments (Table 7).

Table 5. Time spent $\left(\mathrm{h} \cdot \mathrm{d}^{-1}\right)$ within $100,200,400$, and $600 \mathrm{~m}$ of the target and endpoint of herding (upland salt location) by global positioning system-collared cows that were herded to salt (HERD), herded to salt and low-moisture block supplements (HERD-SUPP), and allowed to roam freely (control). Orthogonal contrasts were used to compare cows that were herded (HERD and HERD-SUPP pooled) with controls and to compare the HERD and HERD-SUPP treatments.

\begin{tabular}{|c|c|c|c|c|c|c|}
\hline \multirow{2}{*}{$\begin{array}{l}\text { Time spent near salt in } \\
\text { target areas }\left(h \cdot d^{-1}\right)\end{array}$} & \multicolumn{4}{|c|}{ Treatment means } & \multicolumn{2}{|c|}{ Orthogonal contrasts $^{1}$} \\
\hline & Control & HERD & HERD-SUPP & SE & Herded vs. control & HERD vs. HERD-SUPP \\
\hline Within $100 \mathrm{~m}$ & 0.1 & 1.2 & 1.2 & 0.3 & 0.10 & 0.86 \\
\hline Within $400 \mathrm{~m}$ & 0.6 & 3.5 & 3.2 & 0.4 & 0.03 & 0.62 \\
\hline Within $600 \mathrm{~m}$ & 0.9 & 5.1 & 4.7 & 0.2 & 0.01 & 0.32 \\
\hline
\end{tabular}

${ }^{1} P$ values from the orthogonal contrasts are presented. 
Table 6. Terrain use and proportion of the cows observed in areas with riparian zones during the morning (0630 to 0800 hours) and evening (1930 to 2100 hours) when animals were herded to salt (HERD), herded to salt and low-moisture block supplements (HERD-SUPP), and allowed to roam freely (control). Orthogonal contrasts were used to compare cows that were herded (HERD and HERD-SUPP pooled) with controls and to compare the HERD and HERD-SUPP treatments.

\begin{tabular}{|c|c|c|c|c|c|c|}
\hline \multirow[b]{2}{*}{ Attribute } & \multicolumn{4}{|c|}{ Treatment means } & \multicolumn{2}{|c|}{ Orthogonal contrasts ${ }^{1}$} \\
\hline & Control & HERD & HERD-SUPP & SE & $\begin{array}{c}\text { Herded vs. } \\
\text { control }\end{array}$ & $\begin{array}{l}\text { HERD vs. } \\
\text { HERD-SUPP }\end{array}$ \\
\hline \multicolumn{7}{|l|}{ Morning } \\
\hline Slope, ${ }^{\circ}$ & 3.8 & 5.0 & 5.6 & 0.7 & 0.23 & 0.62 \\
\hline Elevation, m & 1662 & 1672 & 1673 & 4 & 0.18 & 0.82 \\
\hline Water, m & 181 & 195 & 240 & 24 & 0.35 & 0.32 \\
\hline Distance from the Musselshell River, $m$ & 918 & 1071 & 975 & 115 & 0.53 & 0.61 \\
\hline Use of riparian areas, $\%$ & 39.4 & 43.1 & 31.1 & 7.2 & 0.82 & 0.36 \\
\hline Use of target areas, \% & 5.6 & 6.7 & 12.0 & 6.0 & 0.73 & 0.51 \\
\hline \multicolumn{7}{|l|}{ Evening } \\
\hline Slope, ${ }^{\circ}$ & 3.8 & 4.8 & 4.7 & 0.8 & 0.43 & 0.93 \\
\hline Elevation, m & 1658 & 1685 & 1677 & 9 & 0.17 & 0.57 \\
\hline Water, m & 132 & 236 & 334 & 39 & 0.09 & 0.22 \\
\hline Distance from the Musselshell River, $\mathrm{m}$ & 925 & 1353 & 1236 & 126 & 0.14 & 0.56 \\
\hline Use of riparian areas, $\%$ & 44.0 & 27.9 & 17.1 & 6.3 & 0.11 & 0.35 \\
\hline Use of target areas, \% & 1.1 & 25.0 & 29.7 & 5.8 & 0.07 & 0.39 \\
\hline
\end{tabular}

${ }^{1} P$ values from the orthogonal contrasts are presented.

\section{Riparian Stubble Heights}

Stubble heights in the riparian areas associated with the North Fork of the Musselshell River were $8.1 \pm 2.3 \mathrm{~cm}$ higher $(P=0.07)$ when cattle were herded than for the control $(15.3 \pm 1.9 \mathrm{~cm})$. There were no differences $(P=0.69)$ in stubble heights along the Musselshell River between the HERD $(22.8 \pm 1.9 \mathrm{~cm})$ and HERD-SUPP $(24.0 \pm 1.9 \mathrm{~cm})$ treatments. Stubble heights associated with other perennial streams were not affected by treatment $(P=0.96)$

\section{Upland Forage Utilization}

On uplands, overall forage utilization was low $(9.2 \pm 0.7 \%)$. Upland forage utilization was not affected $(P>0.20)$ by paddock, year or treatment (Table 8 ). When evaluated over all treatments, upland forage utilization was not affected by elevation or distance to water $(P>0.20)$. There was limited evidence that forage utilization was lower on steeper slopes $(P=0.10)$. Treatments did not interact with elevation or slope $(P>0.20)$, but there was an interaction $(P=0.03)$ with treatment and distance to water. Forage utilization decreased as distance to water increased for the control and HERD treatments, but not for the HERD-SUPP treatment (Table 8).
To visualize the results of the analysis of covariance, separate simple linear regression analyses were conducted for each treatment. Upland forage utilization was regressed on distance to water (Fig. 2). Regression coefficients (slopes) were negative for the control $\left(-0.012 \pm 0.004 \% \cdot \mathrm{m}^{-1}\right)$ and HERD $\left(-0.005 \pm 0.003 \% \cdot \mathrm{m}^{-1}\right)$ treatments and positive for HERDSUPP $\left(0.010 \pm 0.006 \% \cdot \mathrm{m}^{-1}\right)$ treatment.

Forage utilization within $600 \mathrm{~m}$ of the target was $10.0 \pm 2.5$ percentage points greater $(P=0.06)$ when LMB supplement was available than when only salt was available (Fig. 3). Forage utilization in the target area was greater for the HERD-SUPP treatment than in the control $(P=0.09)$ and HERD treatments $(P=0.07)$.

\section{DISCUSSION}

\section{Effectiveness of Herding}

Moving cow-calf pairs from streams to uplands using lowstress herding at midday was an effective approach to reduce time spent by cattle near streams. Telemetry data showed that cows that were herded used higher elevations and spent less time near streams. In addition, visual observations provided

Table 7. Fecal abundance in uplands and riparian areas associated with the North Fork of the Musselshell River and other perennial streams when cattle were herded to salt (HERD), herded to salt and low-moisture block supplements (HERD-SUPP), and allowed to roam freely (control). Orthogonal contrasts were used to compare cows that were herded (HERD and HERD-SUPP pooled) with controls and to compare the HERD and HERD-SUPP treatments.

\begin{tabular}{lrrrrrrr}
\hline & \multicolumn{3}{c}{ Treatment means, $\mathrm{kg} \cdot \mathrm{ha}^{-1}$} & & \multicolumn{2}{c}{ Orthogonal contrasts $^{1}$} \\
\cline { 2 - 3 } \multicolumn{1}{c}{ Location } & Control & HERD & HERD-SUPP & SE & & Herded vs. control & HERD vs. HERD-SUPP \\
\hline Musselshell River & 113.2 & 59.1 & 64.7 & 11.4 & 0.07 & 0.76 \\
Other riparian areas & 70.5 & 110.3 & 62.4 & 37.4 & 0.76 & 0.46 \\
Uplands & 7.1 & 3.5 & 5.4 & 3.7 & 0.62 & 0.75 \\
\hline
\end{tabular}

${ }^{1} P$ values from the orthogonal contrasts are presented. 
Table 8. Mean squares (MS) and regression coefficients from analyses of covariance representing the sources of variation used to explain differences in upland forage utilization.

\begin{tabular}{|c|c|c|c|c|}
\hline Effect $^{1}$ & df & MS & $P$ value & Regression coefficients \\
\hline Paddock & 2 & 63.9 & 0.52 & - \\
\hline Year & 2 & 36.5 & 0.69 & - \\
\hline Treatment & 1 & 15.1 & 0.86 & - \\
\hline Slope, ${ }^{\circ}$ & 1 & 275.4 & 0.10 & $-0.308 \pm 0.330$ \\
\hline Elevation, m & 1 & 81.0 & 0.36 & $-0.025 \pm 0.057$ \\
\hline Distance to water, m & 1 & 6.8 & 0.79 & $0.011 \pm 0.006$ \\
\hline Slope by treatment, ${ }^{\circ}$ & 2 & 37.9 & 0.68 & \\
\hline Control & & & & $-0.129 \pm 0.442$ \\
\hline HERD & & & & $0.182 \pm 0.405$ \\
\hline HERD-SUPP & & & & 0 \\
\hline Elevation by treatment, $\mathrm{m}$ & 2 & 11.5 & 0.89 & \\
\hline Control & & & & $-0.021 \pm 0.074$ \\
\hline HERD & & & & $0.012 \pm 0.076$ \\
\hline HERD-SUPP & & & & 0 \\
\hline Distance to water by treatment, $\mathrm{m}$ & 2 & 357.1 & 0.03 & \\
\hline Control & & & & $-0.021 \pm 0.008$ \\
\hline HERD & & & & $-0.016 \pm 0.008$ \\
\hline HERD-SUPP & & & & 0 \\
\hline Error & 171 & 97.9 & & \\
\hline
\end{tabular}

found near perennial streams at midday were herded to upland target areas where low-moisture block supplement was placed.

some evidence that cows that were herded used higher elevations and were farther from the North Fork of the Musselshell and water in the evenings. In the early morning, differences between the herded and control cattle were not observed. Fecal abundance and stubble heights near the North Fork of the Musselshell River also showed that herding reduced the extent of grazing in riparian areas. These results support an anecdotal study in Idaho that found that intensive herding reduced cattle use in riparian areas (Butler 2000).

The extra time that herded cattle spent in the upland target area was roughly equivalent to the decrease in time spent near streams over controls. Cattle spent an average of $3.9 \mathrm{~h}$ more time within $600 \mathrm{~m}$ of the target and endpoint of herding, and time spent within $100 \mathrm{~m}$ of perennial and ephemeral streams decreased by an average of $4.6 \mathrm{~h}$. Typically, cattle spend the afternoon in riparian areas after traveling to water in mid to late morning and then leave the riparian in the evening as temperatures begin to cool (Porath et al 2002; Parsons et al. 2003). Rather than spending the afternoon and early evening near streams, herded cattle in this study spent that time in upland areas.

The success in reducing riparian use demonstrated in this study is somewhat surprising considering that the cattle used were naïve 2 -year-old heifers and herding lasted only 1 mo. Morrison (2002) found that 2-year old cows spent more time in riparian areas than older cows, and Bailey et al. (2006) observed that younger cows used gentler slopes and areas closer to water than older cows. Using naïve younger animals allowed us to avoid any carryover effects of treatments from one year to another, but it also may have limited the potential effectiveness of herding. Butler (2000) observed that the effectiveness of herding cattle from riparian areas increased over time. If cattle had been herded for a longer period or if the same cows were used on subsequent years, the effectiveness may have been even higher.

Stocking levels in this study were relatively light. Cows had more than sufficient forage in riparian areas to spend all their time there. Free-roaming control cows spent over half of their time within $100 \mathrm{~m}$ of perennial and ephemeral streams even though those made up only $15 \%$ of the paddock area. Even at these light stocking levels, herding resulted in measurably higher stubble heights $(8.1 \mathrm{~cm}$ greater $)$ in the focal riparian area, the North Fork of the Musselshell River, than if cattle were allowed to roam freely.

\section{Effectiveness of Supplement Placement}

Placement of LMB at the target area did not affect cattle grazing use near the North Fork of the Musselshell River or other perennial and ephemeral streams. The HERD and HERD-SUPP treatments were very similar with respect to cattle use of riparian areas. However, forage utilization was 10 percentage points higher within the target area (within $600 \mathrm{~m}$ of salt and the endpoint of herding) when LMB were available. Bailey and Welling (1999) and Bailey et al. (2001) found that forage utilization within $600 \mathrm{~m}$ of LMB was 10-20 percentage points greater than in areas farther from supplement during fall and winter cattle grazing studies. In addition, supplement placement in this study appeared to change frequently observed relationships between forage utilization and distance to water. For the upland forage utilization data, there was an interaction between the continuous variable distance to water and treatments. For the control and HERD treatments, forage utilization declined as distance from water increased, which is 


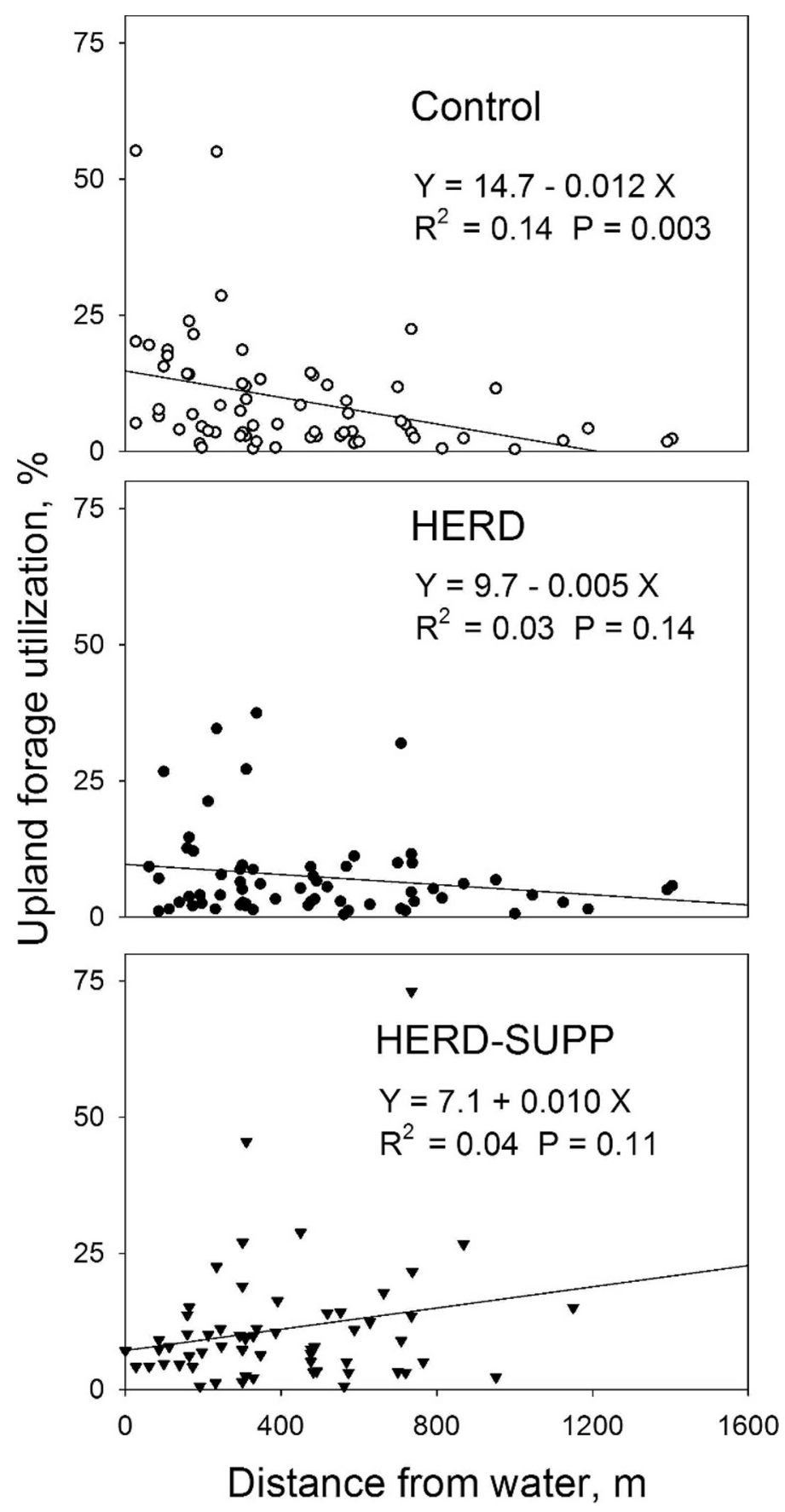

Figure 2. Simple linear regression analyses of upland forage utilization on distance from water for the control, herding to salt (HERD) and herding to supplement and salt (HERD-SUPP) treatments. Analyses of covariance (Table 8) showed that forage utilization was not affected $(P>0.20)$ by treatment, paddock, or year and that slopes for the linear relationships between upland forage utilization and distance water differed among treatments $(P=0.03)$.

the commonly observed relationship (Valentine 1947; Cook 1966). Forage utilization did not decline at farther distances from water when LMB supplement was available.

Telemetry data and cow observations did not support an increase in cattle use of target areas with supplement placement. The time spent by GPS-collared cows within the target area was similar for the HERD and HERD-SUPP

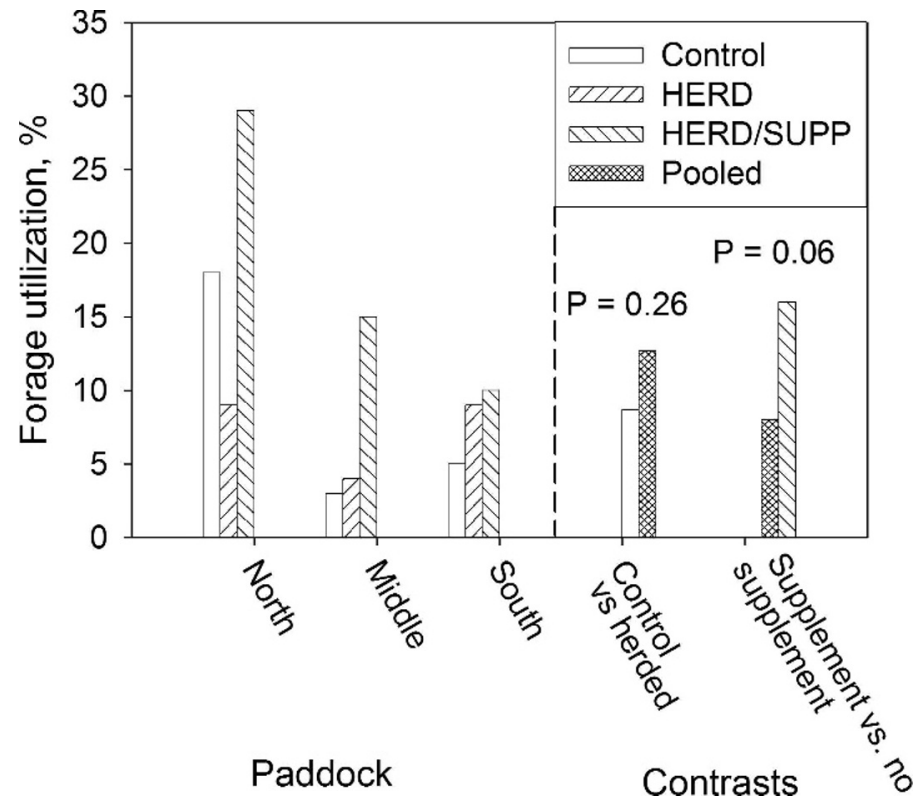

Figure 3. Average forage utilization observed within upland target area (within $600 \mathrm{~m}$ of the upland target and the endpoint of herding) in each paddock during the study. These nine values were the data used in the Latin-square statistical analyses that evaluated forage utilization in target areas. Treatments included a free-roaming control, herding to salt (HERD), and herding to supplement and salt (HERD-SUPP). Orthogonal contrasts were used to compare the pooled effect of herding (HERD and HERD-SUPP) with the control and to compare the effect of supplement placement (HERD-SUPP) with no supplement (HERD and control pooled).

treatments, and the proportion of the cows observed in target areas in the morning and evening were similar. One explanation for this might be that cows in the HERD treatment may have been engaged in other activities, such as resting, to a greater degree than the HERD-SUPP cattle. However, an analysis of data from the activity sensors on the GPS collars (data not reported) did not indicate any differences between treatments for activity (active vs. resting) within the target areas. LMB intake in the South paddock was less than half of the intake observed in the other 2 paddocks, which probably contributed to lower time spent in the target area. The most likely explanation for the similar time spent in target areas by cattle in the HERD and HERD-SUPP treatments are some unique factors for one of the three paddocks. In the North and Middle paddocks the HERD-SUPP treatment spent over 1 and $2 \mathrm{~h}$ more per day in the target area, respectively, than the HERD treatment (Fig. 4). In the South paddock, the HERDSUPP treatment spent almost $5 \mathrm{~h}$ less in the target area than the HERD treatment. The South paddock differed from the other paddocks because there was a perennial spring at the edge of the target area (Fig. 1). If the observations within $50 \mathrm{~m}$ of this spring are excluded, then the HERD-SUPP treatment only spent $1.6 \mathrm{~h}$ less in the target area than the HERD treatment in the South paddock. Another unique factor in the South paddock is the time spent near the target area before herding began. When cattle were first placed in the South paddock, they were herded to the perennial spring next to the target area, because it was the closest reliable water source from the paddock entry point 


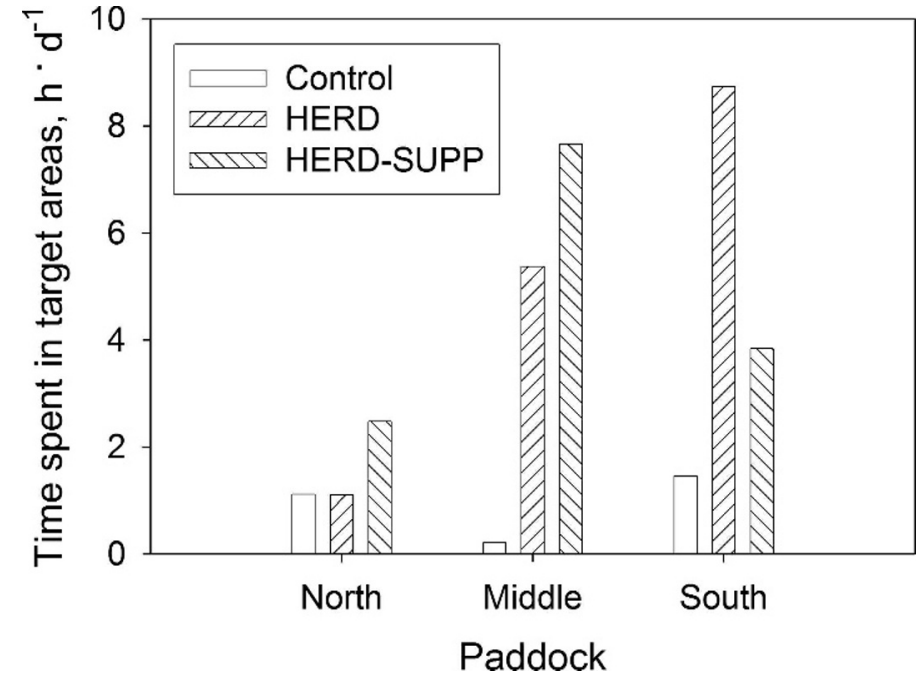

Figure 4. Time spent by global positioning system-collared cows within upland target area (within $600 \mathrm{~m}$ of the upland target and the endpoint of herding) in each paddock during the study. These nine values were the data used in the Latin-square statistical analyses that evaluated time spent in target areas. Treatments included a free-roaming control, herding to salt (HERD), and herding to supplement and salt (HERD-SUPP).

and was still $2.0 \mathrm{~km}$ from the Musselshell River. In 2002, the HERD-SUPP treatment was in the South paddock, and cows remained near the spring and target area for 3 consecutive days after entering the paddock. Cattle then traveled to the Musselshell River and herding began. When the HERD treatment was in the South paddock during 2003, cows remained near the spring and target area for 8 consecutive days. On the ninth day after entry, cows traveled to the Musselshell River and herding began. In 2004, the South paddock contained the control, and cows stayed at the spring between 2-4 d before traveling to the Musselshell, about a third of the cows stayed $2 \mathrm{~d}$ and the remainder of herd stayed $4 \mathrm{~d}$. We do not know the reason why cattle stayed $5 \mathrm{~d}$ extra at the spring next to the target area during 2003. All attempts were made to make the entry into the paddocks each year as similar as possible. If the time before herding began is excluded, the difference between HERD-SUPP and HERD treatments in the South paddock is $3.5 \mathrm{~h}$ instead of almost $5 \mathrm{~h}$. Because of these factors, it is conceivable that cattle in the HERD-SUPP treatment could have grazed upland areas within the South paddock target area more than the HERD treatment even though they spent less total time there (Figs. 3 and 4).

Anecdotal observations of the herders in this study suggested that placement of $\mathrm{LMB}$ reduced the effort required to herd cattle to target areas. Cattle usually increased the travel speed from a walk to a trot as they approached with $200 \mathrm{~m}$ of supplement. Additional research is needed to examine the interactions of strategic supplement placement and low-stress herding on cattle behavior and forage use of nearby areas.

\section{Potential of Herding and Supplement Placement as a Management Tool}

Not only was low-stress herding effective in reducing cattle use of riparian areas, it was effective in focusing grazing in an area that typically receives little grazing use. In combination with supplement placement, forage utilization was increased by 10 percentage points within a $600-\mathrm{m}$ radius target area. This grazing occurred in upland areas with lower forage quality than was available in riparian areas. If cattle grazing can be focused as suggested in this study, forage quality of wild ungulate habitat in specific areas within pastures may be able to be improved without the need for additional fencing or water development. Cattle grazing using low-stress herding and supplement placement could also be used to develop fire breaks at prescribed locations. However, additional research is needed to develop and refine the techniques required to focus cattle grazing and evaluate its practicality.

\section{MANAGEMENT IMPLICATIONS}

Low-stress herding of cattle away from streams to uplands at midday is an effective tool to reduce cattle grazing impacts in riparian areas. Midday herding appears to reduce cattle use of riparian areas and increase use of upland areas in the afternoon and evening. Placement of LMB at the endpoint of herding does not appear to provide any additional benefit for reducing cattle use near streams but does increase the amount of forage utilization in upland areas within $600 \mathrm{~m}$ of supplement sites.

\section{ACKNOWLEDGMENT}

The authors would like to thank the Bair Ranch, Martinsdale, Montana, for their cooperation and help in conducting this research.

\section{LITERATURE CITED}

BAlLEY, D. W. 2004. Management strategies for optimal grazing distribution and utilization of arid rangelands. Journal of Animal Science 82:E147-E153.

Bailey, D. W., M. R. KeIL, And L. R. RitTenhouse. 2004. Research observation: daily movement patterns of hill climbing and bottom dwelling cows. Journal of Range Management 57:20-28.

Bailey, D. W., H. C. VanWagoner, and R. Weinmeister. 2006. Individual selection has the potential to improve uniformity of grazing on foothill rangeland. Rangeland Ecology and Management 59:351-358.

Bailey, D. W., and G. R. Welling. 1999. Modification of cattle grazing distribution with dehydrated molasses supplement. Journal of Range Management 52:575-582.

Bailey, D. W., G. R. Welling, and E. T. Miller. 2001. Cattle use of foothills rangeland near dehydrated molasses supplement. Journal of Range Management 54:338-347.

Butler, P. J. 2000. Cattle distribution under intensive herded management. Rangelands 22:21-23.

Cook, C. W. 1966. Factors affecting utilization of mountain slopes. Journal of Range Management 19:200-204.

Cook, C. W., and J. StuBbendieck. 1986. Range research: basic problems and techniques. Denver, CO, USA: Society for Range Management. $317 \mathrm{p}$.

Delcurto, T., M. Porath, C. T. Parsons, and J. A. Morrison. 2005. Management strategies for sustainable beef cattle grazing on forested rangelands in the Pacific Northwest. Rangeland Ecology and Management 58:119-127.

JoHnson, D. H. 1999. The insignificance of statistical significance testing. Journal of Wildlife Management 63:763-772.

Krysl, L. J., M. E. Branine, A. U. Cheema, M. A. Funk, and M. L. Galyean. 1989. Influence of soybean meal and sorghum grain supplementation on intake, digesta kinetics, ruminal fermentation, site and extent of digestion and 
microbial protein synthesis in beef steers grazing blue grama rangeland. Journal of Animal Science 67:3040-3051.

LitTell, R. C., G. A. Milliken, W. W. Stroup, and R. D. Wolfinger. 1996. SAS system for mixed models. Cary, NC, USA: SAS Institute. 633 p.

Moen, R., J. PAstor, And Y. Cohen. 1997. Accuracy of GPS telemetry collar locations with differential correction. Journal of Wildlife Management 61:530-539.

Morrison, J. A. 2002. The influence of cow age on grazing distribution and utilization of mountain riparian areas and adjacent uplands [thesis]. Corvallis, OR, USA: Oregon State University. $101 \mathrm{p}$.

Parsons, C. T., P. A. Momont, T. DelCurto, M. Mclnnis, and M. L. Porath. 2003. Cattle distribution patterns and vegetation use in mountain riparian areas. Journal of Range Management 56:334-341.

Porath, M. L., P. A. Momont, T. DelCurto, and M. Mclnnis. 2002. Offstream water and trace mineral salt as management strategies for improved cattle distribution. Journal of Animal Science 80:346-356.

Roath, L. R., and W. C. Krueger. 1982. Cattle grazing and behavior on a forested range. Journal of Range Management 35:332-338.

SAS Institute. 1999. SAS/STAT user's guide, Version 8. Cary, NC, USA: SAS Institute, Inc. 1848 p.
SkovLIN, J. M. 1957. Range riding-the key to range management. Journal of Range Management 10:269-271.

Sмıтн, B. 1998. Moving 'em, a guide to low stress animal handling. Kamuela, HI, USA: Graziers Hui. 352 p.

Smith, M. A., J. D. Rodgers, J. L. Dodd, And Q. D. Skinner. 1992. Declining forage availability effects on utilization and community selection by cattle. Journal of Range Management 45:391-395.

Steel, R. G. D., And J. H. Torrie. 1980. Principles and procedures of statistics. New York, NY, USA: McGraw-Hill. 633 p.

Tate, K. W., E. R. Atwill, N. K. McDougald, M. R. George, and D. Witt. 2000. A method for estimating cattle fecal loading on rangeland watersheds. Journal of Range Management 53:506-510.

US Forest Service. 1980. Utilization gauge: an instrument for measuring the utilization of grasses. Rocky Mountain Forest and Range Experiment Station Publication. Wheaton, IL, USA: American Slide-Chart.

Valentine, K. A. 1947. Distance from water as a factor in grazing capacity of rangeland. Journal of Forestry 45:749-754.

Wilk, M. B., And O. Kempthorne. 1957. Non-additives in a Latin-square design. Journal of the American Statistical Association 52:218-236. 